\title{
TRANSFORMING BREXIT BRITAIN
}

ANDREW RYDER ${ }^{l}$

\begin{abstract}
The article gives an overview of the key cultural and structural factors behind nationalist populism in Britain and the decision to leave the European Union as a result of the referendum staged in 2016 (Brexit). The article seeks to identify socio-economic and cultural changes that might counter nationalist populism in Britain through transformative change centered on a renewed Social Europe, a revived civil society, constitutional reform and critical multiculturalism.
\end{abstract}

KEYWORDS: Brexit, populism, securitization, social Europe, transformative change, critical multiculturalism

\section{INTRODUCTION}

In the 2005 general election, Michael Howard, leader of the Conservative Party, ran a highly populist electoral campaign guided by the lobbyist Lynton Crosby who became notorious for the emotive scapegoating speech acts and tactics that featured in his campaigns. Crosby's style of campaigning gave rise to the term "dog whistle" politics - coded language that appears to mean one thing to the general population, but has an additional, different, or more specific resonance for a targeted subgroup often centered on nativism and reactive forms of national identity. The campaign coordinated by Crosby in 2005 sought to surf the demonization of Gypsies and Travellers and migrants which had been orchestrated over a number of years by the tabloid media like The Sun newspaper which ran a series of anti-Traveller articles entitled "Stamp on the Camps." Conservative leader Howard claimed that Gypsies and Travellers were unfairly benefitting from the Human Rights Act and a "rights culture" which

\footnotetext{
1 Andrew Ryder is an associate professor at the Corvinus University of Budapest and associate fellow at the Third Sector Research Centre of the University of Birmingham; e-mail: andrew.ryder@unicorvinus.hu
} 
privileged a minority above the majority that offended the British sense of "fair play" (Ryder, 2015).

At the time of the Howard/Sun campaign I was working as a policy development expert for Gypsy and Traveller civil society and had direct insight into this political moment. This incident seemed to represent a turning point, showing that a mainstream party in the British political system could play upon national identity and insecurity in a racialized context to mobilize support. This was not to be an isolated aberration; such invective seems to have increased its influence in shaping political discourse in Britain, culminating in Brexit, an event which is very much part of the populist turn.

What is populism? Populism appeals to the masses through speech acts which resonate with the emotions, including the anger of the masses. This can include forms of nativism and xenophobia. Populism is also an appeal to folkloric traditions and a desire to preserve and maintain idealized notions of national identity, which often encompass jingoism and bombast. Populism also encompasses a form of paranoia where exaggeration, suspiciousness, and conspiratorial fantasy are rife. Populism is an outlook which lacks refinement and complexity, considered by some to be crude and simplistic. It voices the most base thoughts and anxieties of the masses, which in previous times might have been easily dismissed as demagoguery or opportunism (Mudde and Kaltwasser, 2017).

Identity has offered a number of communities, particularly those suffering from marginalization and profound change, something of an anchor and sense of certainty in a world that is in a state of flux produced by de-industrialization, globalization, mass communication, and conflict (Woodward, 2000). These identities can be condensed into a rigid and uniform sameness where difference is despised (Young, 1999). Brexit can be viewed as a form of paradigm shift, in which public thought about identity and nationhood is being radically and reactively re-orientated. Brexit is a shaper of identity, a frame used to interpret the past and present.

Change, and the trauma and dislocation this can cause, as well as the positives it heralds (namely modernization and renewal) are challenges that politicians have grappled with for centuries. The British response has often been to blend innovation with tradition and forge a consensus that appeals to a broad section of the electorate. One such example was the development of "One Nation" conservatism in the nineteenth century which stressed the importance of preserving established institutions and traditional values, but, coupled with political democracy and a social and economic program was claimed could benefit all, including the newly enfranchised working class. The Conservative prime minister Benjamin Disraeli, who was one of the first and most influential 
proponents of One Nation Toryism, declared in a speech made in Edinburgh in 1867:

"In a progressive country change is constant, and the question is not whether you should resist change which is inevitable, but whether that change should be carried out in deference to the manners, the customs, the laws, and the traditions of people, or whether it should be carried out in deference to abstract principles and arbitrary doctrines." (cited in Blake, 1970, 363)

There is a third option concerning blending abstract principles with tradition in pursuit of reform; an option that characterizes Disraeli's One Nationism whereby a large section of the working class were enfranchised and important social reforms were introduced in tandem with an orchestrated sense of imperial destiny which bolstered certain elitist notions. Disraeli's comments are of relevance to the present day: accordingly, this article seeks to map out a course by which institutions and traditions can be reinterpreted and revived using abstract principles like social justice and deliberative and participatory democracy. The high point of One Nationism was probably the age of consensus in the post-war period, sometimes referred to as the "Glorious Thirty" (Les Trente Glorieuses) (Fourastié, 1979) when cross-party consensus saw British policy committed to full employment and an active welfare state in a mixed economy managed in accordance with the economic principles of Keynes. One Nationism became a popular leitmotif of the left and right in British politics. Such was the allure of One Nationism that Ed Miliband, when leader of the Labour Party, sought to depict Labour as a One Nation party in contrast to the austerity and "small state" thinking of Cameron's premiership (Cruddas, 2013).

I agree with Foucault's (2008) assertion that the trilateral balance between the state, markets, and civil society has become unbalanced, with the market emerging as dominant. A central part of the argument propounded in this article is that an egalitarian Britain and Europe are prerequisites for democratic renewal and inclusive forms of identity. This article thus makes reference to the need for transformative, deep, and fundamental cultural and structural change but argues that such change can take place through the traditions, institutions and values which are inherent to the British way of life. 


\section{Social Justice}

For the past decade, Europe has faltered economically, being in the grip of a financial crisis which was triggered by the near economic meltdown caused by the financial crisis in 2008/9. The "Double Movement" (Polanyi, 1944) the push for social protection against laissez-fair marketization - appears to have been irrevocably undermined. As the Financial Times noted in comments which reveal the global and cultural significance of the Brexit phenomenon, the Brexit victory may be "the moment when the West started to unravel" (Wolf, 2016). Some would argue that this turn of events was the inevitable consequence of the dominance of the Washington Consensus, whereby neoliberalism and marketization have led to an emphasis on deregulation and profitability. Rather than weakening such forms of capitalism, the crisis bolstered it through austerity regimes which cut back on welfare programs, shrinking the state to levels which surpassed the greatest aspirations of Thatcherism. In Britain there was some irony in this development, as David Cameron, the prime minister who presided over these cuts, had portrayed himself as being of the One Nation conservative tradition, in contrast to the more partisan political philosophy of Thatcherism. In a further irony, it was Cameron's inability to face down the radical right in his own party, coupled with a fear of the rise of UKIP, which led to his pledging a referendum in the 2015 election, a pledge which led to his own downfall when the Remain campaign narrowly lost the resulting poll.

Following Cameron's departure, conservatism under Theresa May and then Boris Johnson remained wedded to neoliberal orthodoxies. In fact, their support for forms of hyperglobalism hailed the prospects of a hard Brexit (leaving the EU customs union and negotiating independent trade deals) as leading to a renewal of British success: namely, "Global Britain." Brexit has been heralded as a chance to complete the "Thatcher revolution" (Lawson, 2016). Also, in seeking to deter a soft Brexit by ending freedom of movement, the Conservatives have sought to manipulate anti-migrant sentiment, while in this process nativist rhetoric has entered the political mainstream. A hard Brexit promises not just radical economic freedoms, but, as with Thatcherism, a renewed sense of national identity and pride. Conservative support for Brexit is couched as an effort to protect and uphold British sovereignty. Such is the intensity of the influence of this English nationalism that the Conservatives appear willing to abandon another tenet of One Nationism; namely, a commitment to preserve the Union of the UK. The Conservatives have paid little attention to the protests and concerns of Scottish nationalists about a hard Brexit, thus bolstering calls for a new independence referendum (Hayton, 2018). The Conservative Party has shown a propensity to metamorphose into 
something more akin to a populist entity, giving credence to the predictions of Polanyi and Dahrendorf that neoliberalism can potentially transform into forms of fascism and authoritarianism in times of crisis. Such detours and innovations, as reflected by nativist and isolationist sentiments that are pronounced in desires for a hard Brexit, ostensibly might appear to contradict globalization, but the fusion of neoliberalism and nationalist populism seems to be a relatively simple form of political merger, facilitating further downsizing and the dilution of social protections (Fekete, 2016).

From a review of the 2016 referendum result it became evident that there is a strong correlation between wealth and income and support for Brexit, with a large proportion of low-income groups and depressed areas supporting Brexit. Thus, a new social contract should be part of the counter-narrative and response to Brexit. At times, however, leftist thinking has been more in kilter with populist trends, as reflected in notions that Britain's socialist future could be assured outside of the EU (as encapsulated in "Lexit," a leftist version of Brexit, which perceives the EU as an enforcer of neoliberal policies).

In a globalised world, the notion of "socialism in one country" is dangerously outdated. Given the opposition to such changes from economic elites and the potential for flights of capital in retaliation, such change would need to take place in unison within international trading blocs. This was the logic of the EU before it became market driven and embraced ordoliberalism: the founders of the EU project had envisaged forms of economic and social solidarity for safeguarding the European social model (Crouch, 2018). Returning to earlier conceptions of the European project will be integral to persuading Britain to remain or return and bring about a new social contract across Europe.

EU structural and regional funds have not been able to address economic disparities, a failure compounded by the financial restrictions of the Stability and Growth Pact promoted by German Chancellor Angela Merkel to bolster the Eurozone, which, according to critics, accentuated the problems of the financial crisis through austerity policies (Avis, 2014). The ordoliberal austerity imposed upon the Eurozone has also compromised the democratic accountability of the EU, further eroding public trust and support (Farnsworth and Irving, 2018).

The concept of "Social Europe" stresses the value of increasing labor market participation, places much more emphasis on active welfare state measures, introducing supply-side efforts at job creation, creating measures to provide security other than life-time job tenure, and prioritizing efforts to combat social exclusion. Social Europe might offer a panacea for the ills of Europe (Seikel, 2016). DiEM25 is campaigning for a European New Deal, a call echoed by the Confederation of German Trade Unions which has called for a Europeanstyle Marshall Plan. 
A policy centered on a renewed Social Europe would not be able to revive the Keynesian mixed economy of the post-war era, as expansion during that period was based on rapid growth. Such a model may not be sustainable environmentally because of the level of resources that were and would be devoured to fuel rapid growth. In addition, post-war growth was also based on cheap materials and exploitation of low-wage labor from regions of the periphery, and within the new globalised economic order such terms could not be replicated (Benton, 2018). However, these factors, whilst impeding a return to previous models of welfare and socio-economic consensus, do not mean that transformative change is impossible. In the current economic system, unprecedented wealth is owned by a super elite, which could be redistributed through greater levels of progressive taxation and a global tax on elites, as Piketty (2014) has advocated. New socio-economic models will entail less consumerism given the slower rates of growth that would be possible and the environmental restraints needed to limit future damage. The key point though, is that Britain will need to stay in the EU for any future government to have a chance of being able to deliver transformative change; to attempt to do so isolated and outside of the EU would lead to penalties and punishments being inflicted by the market. In addition, a Britain which opts for a harder Brexit outside of the customs union and which is free to make independent trade deals would be following a policy trajectory which seeks to dismantle social protections in order to achieve maximum profitability and competitivity.

\section{TAKING CONTROL}

The political attachment of society to democratic norms, and the values and the procedures of a liberal democratic constitution have been termed Constitutional Patriotism by Habermas (1994); the latter is dependent on rational discussion and debate - principles, some would argue, that were absent in the referendum. In Britain, the Westminster model has held sway (a more centralized form of political governance, as opposed to the continental model whereby forms of proportional representation have a greater tendency to produce a coalition government leading to an emphasis on consensus building and deliberation). In contrast, the Westminster system is more hierarchical and less inclined to compromise. Britain has a restrictive form of representative democracy which compounds voters' sense of alienation from the political process by appearing to act primarily in the interests of elites which appear to be distant and disconnected. The resulting mistrust and alienation from the political establishment meant 
that entreaties for Britain to remain within the EU during the referendum were ignored in some quarters: in fact, Brexit was perceived as an assault on the elitism and vested interests of the political class.

Laclau and Mouffe (1985) contend that liberal democracy and anodyne forms of consensus have created an empty and meaningless form of politics in which politicians in the mainstream sound the same and premise their thoughts and actions on an unquestioning adherence to neoliberalism. Basically, the centre and left of politics has shifted to the extent that the Les Trente Glorieuses and the vision of the social contract it represents have been profoundly undermined. Nationalism and populism have sought to fill this political vacuum with pledges to upend the status quo (Jones, 2014). Laclau and Mouffe advocate a form of democracy which seeks to move away from the essentialism and determinism of traditional radical left politics of the post-war period and embraces a renewed liberal democracy (radical pluralism) as a means by which transformative politics can be advanced. It can be described as the politics of choice, contrast, and contestation (agonism), in which an adversarial politics of "us" and "them" comes into play (Mouffe, 1999). Such views were shaped by Schmitt's (1976) adversarial view of politics, where the chances of reaching consensus are minimized through a collective nation-building dynamic at the centre of politics. In contrast, radical pluralists have sought to focus on frames centered on economic and social justice rather than nationalism.

Fassin has criticized what he perceives as the leftist populism of Laclau and Mouffe, claiming it is fuelled by resentment, which ultimately, as with nationalist populism, cannot be immune to reaction and scapegoating (Hamburger, 2018). This is evident with a faction like the radical left political organization Momentum that operates within the British Labour Party which is committed to grassroots activism and support for the leadership of Jeremy Corbyn. Left populism has at times resorted to crude binary frames to mobilize mass movements. In this sense it has displayed the classic traits of populism, relying on charismatic leadership and a simplistic rhetoric of resentment which crowds out the possibility for independent thought and deliberation. In the factional struggle within Labour between Momentum and its opponents, party members with diverging views are denounced as "plotters" against the leadership of Corbyn, or Blairites wedded to a neoliberal order: a mindset that threatens to undermine the broad-church traditions of the Labour Party. Laclau reflects the stridency of some on the left by deriding Habermas as a naïve universalist on account of his desire to see a consensus forged by deliberation. However, argumentation and deliberation, although being slower and less decisive than coercion and collective "will," might be a more secure means of developing long-term, stable transformative policy trajectories (Garnham, 2007). 
However, Mouffe (2005) does believe that forms of consensus are useful in formulating a common symbolic space centered on the principles of equality and liberty, although there should simultaneously be space for disagreement as to how these principles are applied, with those who do not ascribe to these ideals being excluded from the democratic debate. Rawls (1971) espoused forms of economic consensus about curbing the rapacity of economic elites so that the life chances of the majority are not impinged on. Rawls has been classified as part of the liberal tradition of political philosophy which largely maintained the status quo, but in the wake of four decades of neoliberal hegemony his views could be construed as more egalitarian ones in the present political climate. Indeed, it could be claimed that Rawl's notion of building consensus through an incremental and gradualist progress in the tradition of social democracy could ultimately achieve radical forms of social justice. For some, this was the perceived trajectory of post-war policy in many European states before the advent of neoliberalism, perhaps most successfully achieved in countries like Sweden. In more recent times Habermas has sought to revive notions of consensus based on deliberation within liberal politics, although his writings contain a corresponding commitment to social justice through his call for advocacy to reverse corporate capitalism.

A central question for those interested in progressive politics is whether the radical pluralism of Laclau and Mouffe and the deliberative consensual politics of Rawls and Habermas might be fused. Deliberative politics, it could be argued, has an important advantage over agonism in an age when politics seems to be increasingly characterized by fissure and dissension, as it does not provoke and mobilize the support base of the adversary through polemic and disagreement. Instead, deliberative politics, through dialogue, reinterpretation, and reorientation, seeks to dilute the views of its adversaries and convert them. The challenge is to achieve such a state of affairs without recourse to the anodyne politics of the neoliberal consensus that Mouffe and Laclau condemn, and which many contend has failed. In the Les Trente Glorieuses consensus, deliberation, and social justice formed a gradualist trajectory based on forms of welfare and social protection, enabling society to achieve what some have termed the "good society," but which was interrupted by the Washington Consensus. Constituencies of opinion that mobilized in support of Brexit, especially in the de-industrialized and "left behind" communities, could be persuaded to reorientate their political aspirations if promised a version of the "good society" that would entail transformative interventionist and redistributive policies with the ability to create work and rebuild communities. This could be part of a counter-narrative to the politics of nativism. In tandem with such interventions, cultural frames would need to be re-orientated through conceptions of identity 
and nationhood that do not rest upon the frame of resentment. Mouffe (1999) has sought to transform antagonism into agonism and marginalize the potency of such reactive frames by accepting that compromises can be achieved with the "adversary" in what are described as temporary respites. Hence, there appears to be the potential for forms of deliberation and consensus-building within radical pluralism.

Mouffe and Laclau support grassroots politics, building on the ideas of Gramsci and the frames of new social movements centered on intersectional notions of gender, sexuality, ethnicity, and economic justice. In this sense, their thought chimes with current leftist populist movements in Europe like Podemos, Syriza, and Labour under Corbyn. Even though Laclau and Mouffe support direct forms of democracy, they note that such is the technical complexity of governance that forms of representative government are inevitable. Thus, it might be possible to fuse aspects of direct and deliberative forms of democracy.

Institutional democracy is a concept that might offer a panacea for the challenges facing modern democracies. It welds diverse approaches to decision making through overlapping forms of representative, participatory, and associative forms of decision-making (O'Donnell, 2018). A transformative political agenda could redistribute both resources and power. Such notions translated into action are evident in Brazil where representative democracy co-exists with empowering forms of localized decision making such as peoples' budgets where local assemblies are consulted about the direction of local spending. A key dynamic of Habermas's (2010) political thought is deliberative democracy, where communicative action and new social movements create consensus and mutual understanding, creating the possibility for citizens to reframe their interests and perspectives in light of a joint search for common interests and mutually acceptable solutions. Cultural and economic transformative change as outlined in this article will necessitate persuasion and education through deliberation.

In an effective representative democracy the furtherance of the "greater good" warrants representatives being endowed with what can be described as "representative judgment," reaching a balance between the individual, plural, and common needs and aspirations of a community in total and translating that into fair and rational decisions that uphold core values (Chalmers, 2017). Representative judgment does not yield to what might be the emotive and temporal views of the mass at a given moment. A lawmaker (member of parliament) should be informed by public opinion and provide a rationale for unpopular decisions they make but not slavishly follow the mood of a given moment, especially as emotions might be stirred in forms of hysteria orchestrated by the media and other such actors (Parvin, 2009). The electorate 
hold the ultimate power, of course, by being able to vote out any lawmaker who they feel has not adequately respected their sentiments.

Rousseau (1762) asserted that representative democracy constituted a loss of freedom, as opposed to direct democracy that articulated the "will" of the people, thus some on the left have been purists in supporting such notions of democracy aligned closely with decentralized decision making in which localized assemblies play a pivotal role. The political thinker Ralph Miliband (1961) derided the Labour Party for being seduced by the parliamentary tradition and losing its radical edge, but support for representative democracy may not necessarily curtail the possibilities of transformative change. Michael Foot as leader of the Labour Party championed the concept of representative judgment, believing members of parliament should be independent minded and not harnessed to the will of local Labour Party management committees (Pugh, 2010). What could be termed "minipublics" composed of deliberative local assemblies, citizen juries, and deliberative polls could be the antidote to political systems that can be characterized as suffering from elitism and a sense of disconnection between lawmakers and voters. Gordon Brown (2019), a former prime minister, recognized the need for a "root-and-branch" national conversation about the direction of Britain when he called for citizen's assemblies to be established, arguing that these regional public hearings would develop new approaches and re-establish trust that has been lost between MPs and their constituents and help guide and inform decisions made about Brexit, thereby breaking the deadlock that has been reached concerning this issue.

The integrity of the political process could be further enhanced by introducing greater regulation and control over political funding. Sixty-one percent of the funds for the Brexit campaign were provided by five rich individuals. Among these contributors was Arron Banks, a wealthy businessman who spent an estimated 11 million pounds on social media from 2011 to promote a Leave agenda (Shipman, 2016). Banks also heavily financed Nigel Farage and is reported to have financed a house and chauffeur for him since 2016 (money which Farage failed to properly record in the EU parliament's register of interests). Questions have been raised as to how Banks could afford to support Leave to the extent he did given the alleged financial difficulties of his business, and questions have been raised about his links with Russia (Sloan and Campbell, 2017). The National Crime Agency though reported in 2019 that it found no evidence of criminality after investigating a series of claims against the Brexit campaign group Leave.EU and Arron Banks. However, greater regulation of funding and even state financing of political parties may be needed to restore trust and transparency in British politics.

The events of Brexit and how the executive sought to use its powers to 
steamroll its interpretation of Brexit through parliament by introducing its Withdrawal Agreement Bill to parliament no less than four times in what was perceived to be an attempt by the administration of Theresa May to wear down and intimidate parliament into supporting the requisite legislation have damaged democracy. The action of the May administration was interpreted by some critics as executive arrogance and bullying that undermined parliamentary conventions, many of which are based on unwritten practice and custom. To ensure that parliamentary tradition is respected in future, a written constitution with strong checks and balances on the power of the executive may be required. The transformation of the House of Lords, with an elected second chamber and proportional representation in the Westminster system coupled with the extension of regional government to the regions of England, would make British politics more consensual and deliberative and similar to continental politics.

The French president Emmanuel Macron has pledged a "rebuilding" of the EU to reverse the breakdown in trust and support that has occurred. According to Macron (2017), this will entail an integrated eurozone with its own financial minister, parliament, and a standalone budget to head off future crises. Critics argue though that Macron's centrist "third way" approach may not be sufficient to meet the challenge of the surge of support for nationalist populism, and such measures may be more of the same hierarchical and technocratic approaches that have already alienated so many in Europe. Some argue for a stronger focus on what has been described as the Social Pillar of the EU, an active and dynamic welfare and growth policy whereby social rights take precedence over the competition rules of the single market in order to create a notion of a "European dream."

\section{THE PUBLIC SPHERE}

The public sphere is a social space where different opinions are expressed, problems of general concern are discussed, and collective solutions might be developed. The media is a central dynamic in this sphere. Critics have long raised concerns about the concentration of media power and ownership in the hands of a small privileged elite in Britain, most notably in relation to Rupert Murdoch, owner of The Sun and The Times. The marketization of the media has also created a mass culture where marketing techniques centered on slogans and emotive manipulation have colonized politics: as noted earlier, "dog whistle politics" have become a more apparent feature of British politics in recent decades. 
The Brexit referendum was something of a culmination of a long process of securitization. Securitization describes how power elites are able to use speech acts to play upon or construct perceptions of insecurity and fear and thus mobilize and frame thought and action to a priority level; an "emergency politics" which sets aside the normal process of decision making (Stritzel, 2007). Post-truth politics is another aspect of what has become an increasingly unstable public sphere where emotions rather than facts are at a premium, and coupled with distorted and sensationalist media reporting such phenomena have done much to undermine the quality of public debate and discourse. New measures are needed to raise the quality, accuracy, and balance of the media, where greater attention is given to those outside the governing class, especially those at the margins, and greater attention is paid to the ethics of journalism and the public information service role of the media.

Print media is in decline and the influence of social media has steadily grown. The Leave campaign enjoyed a dominant role in social media. On Twitter, sentiment was (on average, for much of the campaign) two-thirds in support of Leave, as opposed to a third for Remain (Llewellyn and Cram, 2016). Arron Banks hired the US pollster and referendum expert Gerry Gunster to acquire quantitative data; this involved sophisticated mining techniques whereby personal data was "scraped" from social media such as Facebook accounts. This data was then used to segment the population through classification, and then micro-targeting of the electorate was undertaken to shape voting behavior. Targeting involved the transmission of sharp messages likely to invoke key feelings and anxieties, and was a prominent feature of the Banks-and-Farage-supported "Leave.EU," one of the two principal leave campaign groups in the referendum. The other group was "Vote Leave," which was a more mainstream Conservative operation that hired Aggregate IQ, a software data firm with connections to Cambridge Analytica, a company partly established by Steve Bannon that was used to assist the Trump election campaign. Aggregate IQ built up a core audience and used a Facebook tool called "Lookalike Audiences": an audience-builder which helped identify similar people (Shipman, 2016). This aspect of the campaign is now at the centre of some controversy as it appears that privacy agreements may have been violated. Concerns have been raised about the almost Orwellian use of social media and messaging to influence voting intentions, especially when emotive and non-factual codes are relied upon.

Thus, another important area in need of reform is social media and its influence on decision-making and the privacy of personal data. Aside from more stringent regulations, the large online monopolies of Google and Facebook should be broken up and made subject to greater scrutiny. The British parliament last 
passed substantive legislation on data protection 15 years ago, which Rawnsley (2018) notes is "like trying to govern the airline industry with rules made for hotair ballooning." The European Union has activated a General Data Protection Regulation that will give users more power to opt out of being tracked online and prevent their data being shared with third parties. It is probable, however, that greater enforcement and regulation is needed.

\section{COMMUNITY MOBILIZATION}

Traditionally, civil society has been a bridge and even mediator between government and communities. Under the premiership of David Cameron, promises to bolster and extend the role of civil society in British society were made as part of the "Big Society" agenda. Big Society was a communitarian vision of society that sought to see social capital and volunteerism become an important dynamic in community governance and a key plank in Cameron's efforts to cast himself in the One Nation tradition. In truth, despite the marketing and hype of Big Society, it equaled the "small state" as Cameron's post-financial crisis austerity measures greatly reduced the strength and independence of civil society. Where civil society has survived, it has often found itself tied into service delivery contracts or businesslike operational models. A renewed civil society, coupled with a new sense of constitutional patriotism (see above discussion), is a prerequisite for reinforcing the norms and values that may withstand the reactive populist sentiments of Brexit.

The EU referendum result might have been different if there had been a stronger and more vibrant network of grassroots-orientated civil society groups, particularly in those marginalized communities that voted heavily to leave. An autonomous and well-funded civil society can also help reconnect some of the most marginalized in society. A renewed civil society can facilitate what Freire (1994) envisaged as a catalyst for marginalized groups, supporting them in developing a critical consciousness, and by training and supporting them in participating not just in decision-making but also in economic activity through fostering economic cooperatives and mutualism. Such initiatives might enhance the collective and individual capabilities of communities, forming a subaltern counter sphere (Fraser, 1992). In other words, civil society can constitute a discursive arena where the marginalized can invent and promote counter discourses and formulate oppositional interpretations of their identities, interests, and needs, furthering the politics and policies of redistribution, recognition, and representation. 


\section{CRITICAL MULTICULTURALISM}

In 2019, a report revealed that Brexit identities were stronger than party identities, with the country almost equally divided as to whether they saw themselves as Remain or Leave, both having become frames which encompassed distinct views and values (UK in a Changing World, 2019). An important question is whether this divide can be overcome. In the referendum there was an important correlation between demographics and the vote to leave the EU. Brexit nationalism thus highlights a series of fissures, with poorer communities, especially in the North and Midlands, being more likely to have voted leave than affluent/metropolitan areas that were more cosmopolitan in their outlook. Again reflecting class, the less educated were more likely to vote leave than the educated, while older voters were more likely to vote leave than younger ones. Large numbers of Conservative supporters with more insular conceptions of English identity were also prominent in the constituency supporting Brexit. Approximately 60 percent of over-fifties voted leave, in contrast to the 70 percent of 18-24-year-olds who opted for remain. Older voters could be described as the "carriers of cultural legacy": socialized, indoctrinated, and habituated in a particular cultural milieu. Perhaps the imprint of British exceptionalism, Empire, and war was most evident among this demographic age group.

These divides represent in some cases deep cultural chasms in which an accepted and deeply held liberal-minded tolerance of minorities and difference, strongly evident in metropolitan and urban areas and once deemed to be dominant and mainstream, are in fact deeply at odds with a counter-narrative of fear and resentment that may be found in de-industrialized and rural areas. Cultural resistance to progressive values can be viewed as a silent counterrevolution (Ignazi, 1992). There is in fact a cleavage between cosmopolitan and nationalist mindsets, a cultural civil war that can only be resolved through a deep and intense national conversation about who the British are, and where they think they are going.

The cultural backlash to more liberal and multicultural developments in British post-war society is in part a byproduct of the conservatism of the British media that has instigated a decades-long crusade against liberal values and diversity. As noted at the start of this article, the Sun newspaper's "Stamp on the Camps" anti-Traveller campaign, and a host of other such campaigns centered on attacks on migrants, the bureaucracy of the EU, and the perceived dangers of Islam can be viewed as a "moral panic." Moral panics and a fear of "folk devils" help normalize mainstream institutions, values and community voices (social guardians) who claim that they represent the majoritarian view based on tradition and/or established behavior and who castigate those (folk devils) who 
are deemed to deviate from convention. Successful panics and acts of collective hysteria resonate with deeper historical, cultural, and structural anxieties which can reinforce boundary maintenance in a neurotic form of "us" and "them" (Cohen, 2016).

In response to cultural backlash, there is also a need to nurture inclusive forms of identity and community relations. In the 1960s and 1970s, liberal forms of multiculturalism and integration replaced assimilation, embodying a version of liberal "tolerance" based on the assumption that there was a dominant cultural identity to which incoming ethnic minorities had to adjust, but to whom concessions could be made. Liberal conceptions of multiculturalism could be patronizing and tokenistic. Some minority groups have themselves been critical of multiculturalism, claiming that it caricatures their culture in a simplistic manner which often reduces the presentation of minority cultures to a homogeneous, static, and conflict-free caricature (Sarup, 1991). Critics argue that this version of multiculturalism does not deal with the central cause of racism, such as racist attitudes expressed through teacher hostility and low expectations, bullying, and institutional racism (Bulmer and Solomos, 1999). In addition, liberal forms of multiculturalism have often ignored white culture and failed to celebrate and explore it alongside minority cultures, causing further anger and resentment from white society (Back, 1996). An alternative approach is presented in the form of critical multiculturalism which is intersectional in the sense it is interested in the linkages between race, gender, and class and challenges oppressive behaviors within majority and minority society that might stem from tradition and custom. Such a notion can be described as "twoway integration," where the identities of all ethnic groups, including white majoritarian society in the UK and Europe, undergo processes of change as the overarching national community and sense of identity emerges (Modood, 2012). Such conceptions may be the antidote to the new assimilationism that emerged post $9 / 11$ and the rise of nationalist populism. Critical multiculturalism encourages a form of hyper-pluralism, where innovation and imagination is encouraged but is steered by reason and principle, allowing for meaningful responses to an ever-changing world.

\section{THE MIGRATION DEBATE}

With the accession of Central Eastern European States to the EU, migration from the EU to Britain greatly increased. Migration from within the EU rose from 15,000 individuals in 2003 to 180,000 in 2015. Kaufman (2018) identifies 
immigration as the principal and most decisive factor for those voting "Leave" in the referendum - 33 percent of those who voted Leave thought it was the best chance for Britain to regain control over immigration and its borders (Salter, 2018). Post-industrial austerity-hit communities have been prominent in expressing resentment about migration, in contrast to the enthusiasm about diversity of the more materially fortunate liberal metropolitan elite (Seidler, 2018). The issue of intra- and wider migration has been increasingly securitized and referred to as the cause of unemployment, the rise of the informal economy, and the crisis of the welfare state. Second, the security factor is linked to the "loss-of-control" narrative associated with the issue of sovereignty, borders, and both internal and external security. The third factor is linked to identity, where migrants are seen as a threat to national identity and demographic equilibrium.

As part of the securitized debate around migration, a key argument from the right of political opinion is that freedom of movement and an "influx" of CentralEast-European migrants has led to unemployment, pressure on services, and a loss of English identity in some communities. The reality of the situation though, is that migrants make a positive contribution to the economy, tax revenues, and service delivery in areas like health care (Andor, 2014). English left nationalism accepts some of the central tenets of the Leave trope by asserting that free movement of labor aids the neoliberal economy by depressing wage rates. Others on the left are alarmed at the nativism that such migration prompts, leading to the rise of radical-right parties propelled by a strong anti-immigrant stance, which in some cases is leading to traditional left parties hemorrhaging electoral support (Chakrabortty, 2016). Such sentiments contrast with progressive political sentiments, which advocate robust anti-discrimination policies and measures to counteract the economic manipulation of migrants and wage protection and thus oppose restrictive immigration policies (Global Unions, 2013).

A Social Europe (see discussion above) would raise the socio-economic condition of depressed parts of Central Eastern Europe through redistributive policies and targeting regions and economic sectors suffering from skills shortages as a consequence of intra-migration. Such initiatives could create incentives for workers to stay in their home countries or be replaced through extensive training programs. In migrant-receiving countries where services and the availability of accommodation is under pressure due to migration - often poorer inner-city areas -, it would be of value if the EU and national governments could make available more targeted funds for alleviating such pressures, which are major contributory factors to the undermining of community cohesion. Thus, employment and social standards should be protected not by restrictions but by the enforcement of rights and greater targeted financial support for areas affected by migration. 


\section{CONCLUSION}

The article has presented the argument that austerity and cuts bolstered support for Brexit and were a reflection of the resentment and anxiety of depressed and left-behind communities. Brexit can also be construed as an attempt to revive and promote forms of white identity imbued with notions of exceptionalism, fuelled by a form of English nationalism which is inward looking and deeply nostalgic. These resentments and outlooks have been stoked and framed by tabloid journalism, giving rise to forms of crude rhetoric and forms of populism which threaten to upend British democracy as we know it. The populist turn has been surfed by a range of nationalist politicians, but has included the Conservative Party recasting itself in the populist mould, evidenced by its support for a hard Brexit, and the fact that at the time of writing Boris Johnson had been elected the new leader of the Conservative Party. Johnson, with his personality and media-focused politics, advocacy of a no-deal or hard Brexit and affinity with Trump, is very much a politician shaped in the populist mould.

As noted in the article, the left of British politics has not been immune to the populist surge, with sections of the left advocating a leftist nationalist vision of a Labour exit from the EU (Lexit). The irony is that addressing the root socioeconomic causes of Brexit then remaining in the EU and helping to formulate a Social-Europe response to inequality are essential parts of the counter-response to the forces behind the Brexit phenomenon.

The search for consensus is in itself something very British; a veneration no less of open discussion, reason, and a "one-nation" conception of politics which seeks to bolster the imagined unity of nation by minimizing social inequalities - in other words, the British practice of introducing innovation through existing institutions and practices, or putting "old wine into new bottles." The appreciation of such a stance is evidenced by the fact that around forty Conservative MPs, in response to the growing influence of hard Brexiteers, have formed a political grouping that seeks to protect and uphold the principles of One Nationism and to help steer the country into a softer form of Brexit. Likewise, under Corbyn, Labour sought to portray itself as a champion of consensus by supporting a vision of Brexit that whilst leaving the EU could uphold social protections in an effort to bring the country back together. These efforts to create consensus rest on forms of compromise and caution that fail to address the fundamental causes of Brexit. As suggested in this article, a sustainable form of national unity can only be achieved through transformative change in relation to economic management with enhanced social protection; a notion of identity that is intercultural and inclusive, and, most importantly of all, a rejection of Brexit and the embrace of a stay-and-reform agenda centered on Social Europe. 
It will be evident to the reader that this article advocates the democratization of democracy through the reform of existing institutions within a policy framework that advocates a radical shift away from neoliberalism. The radical Left has often been characterized as seeing the EU as a market-driven project for transnational capitalism in which the free movement of capital can be guaranteed. In contrast, the centre Left is deemed to have embraced the market but perceives the EU as a civilizational project shaped by enlightenment ideals which promote tolerance and egalitarianism (Susen, 2017). This article has sought to fuse these approaches by advocating a reformed EU centered on a renewed Social Europe which is robust in promoting and facilitating intervention and redistribution, but in which the pluralist traditions and institutions of EU Member States can be strengthened through greater media regulation and placing limits on patronage and financial influence in the political system. The article also argues that democracy needs to be bolstered through empowering civil society and complementing representative democracy with new forms of participatory and direct decision making. We live in a time of flux, crisis, and contestation: time will tell which vision - namely, populist nationalism or a new Social Europe - emerges triumphant.

\section{REFERENCES}

Andor, L (2014) Labour Mobility in the European Union - The Inconvenient Truth Lecture, University of Bristol 10th February 2014.

Back, L. (1996) 'New Ethnicities and Urban Culture: Racisms and Cultures in Young Lives', London, Routledge.

Benton, T. (2017 'Beyond neoliberalism, or life after capitalism? A red-green debate', in Bryn, J. \& O'Donnell, M. Alternatives to neoliberalism: Towards equality and democracy, Bristol: Policy Press, pp 195-208.

Blake, R (1970) The Conservative Party from Peel to Churchill, Faber and Faber.

Brown, G (2019) A citizens' assembly is now the only way to break the Brexit deadlock - Guardian 20th January 2019.

Bulmer, M and Solomos, J (1999) Racism, University of Oxford Press,Chakrabortty, A (2016) 'Wolfgang Streeck: the German economist calling time on capitalism', The Guardian $9^{\text {th }}$ December.

Chalmers, D. (2017) 'Brexit and the renaissance of parliamentary authority', The British Journal of Politics and International Relations, 19(4): 663-679.

Cohen, S (2016) Folk Devils and Moral Panics. Notes and References. Appendix. The Creation oft/16 Mods and Rockers. London. MacGibbon \& Kee. 
Crouch, C. (2017) 'Neoliberalism and social democracy', in Bryn, J. \& O’Donnell, M. Alternatives to neoliberalism: Towards equality and democracy, Bristol: Policy Press, pp 195-208.

Cruddas, J, 2013, One Nation Labour: debating the future, London: Labour List. European Commission (2014) - Community-Led Local Development, European Commission 26th March 2014.

Fekete, L. (2017) 'Flying the flag for neoliberalism', Race \& Class, 58(3): 3-22. Foucault, M. (2008) The Birth of Biopolitics; Lectures at the Collège de France 1978-1979, New York: Palgrave MacMillan.

Fourastié, J (1979) Les trente glorieuses ; ou, La Révolution invisible de 1946 à 1975 - Fayard

Freire, P. (1994) Pedagogy of Hope: Reliving Pedagogy of the Oppressed.

Fraser, N. (1992) 'Rethinking the Public Sphere: A Contribution to the Critique of Actually Existing Democracy', in Calhoun, C. J. Habermas And The Public Sphere, MIT Press, pp 109-142.

Gans, H. J. (2011) 'Multiperspectival news revisited: Journalism and representative democracy', Journalism, 12(1): 3-13.

Garnham, N. (2007) 'Habermas and the public sphere', Global Media and Communication, 3(2), pp. 201-214.

Global Unions (2013) The UN High Level Dialogue on Migration and Development must deliver on a rights- based approach to migration, International Trade Union Confederation 23rd January 2013.

Habermas, J. (2010) Germany and the Euro-Crisis: Taxpayers of the eurozone are now on the hook for the financial risks any EU member takes. That makes a coordinated economic policy imperative, The Nation $28^{\text {th }}$ June 2010.

Habermas, J (1994) ‘Citizenship and National Identity', in Steenbergen Bart Van (ed), The Condition of Citizenship, SAGE Publications.

Hamburger, J. (2018) Can There Be a Left Populism?, Jacobin 29th March 2018. Hayton, R (2018) British conservatism after the vote for Brexit: The ideological legacy of David Cameron, The British Journal of Politics and International Relations2018, Vol. 20 (1) $223-238$.

Ignazi. P. (1992) 'The silent counter-revolution: hypotheses on the emergence of extreme right-wing parties in Europe.' European Journal of Political Research 22:3-34.

Avis, J(2014) 'Comfort radicalism and NEETs: a conservative praxis, International Studies', Sociology of Education, 24(3): 272-289.

Jones, B. (2014) 'Ensuring a political space for conflict by applying Chantal Mouffe to post-war reconstruction and development', Progress in Development Studies, 14(3): 249-259. 
Kaufman, E. (2018) Whiteshift: Populism, Immigration and the Future of White Majorities, London: Allen Lane.

Laclau, E. \& Mouffe, C. (1985) Hegemony and Socialist Strategy: Towards a Radical Democratic Politics, London: Verso.

Lawson, N. (2016) Brexit gives us a chance to finish the Thatcher revolution, Financial Times $2^{\text {nd }}$ September 2016.

Miliband, R. (1961) Parliamentary Socialism: A Study in the Politics of Labour, Allen \& Unwin.

Modood, T. (2012) New paradigms in public policy Post-immigration 'difference' and integration The case of Muslims in Western Europe, British Academy.

Mouffe, C. (1993) The Return of the Political, London, New York: Verso Books. Mudde, C and Kaltwasser, C. (2017) Populism: A very short Introduction, Oxford: Oxford University Press.

Parvin, P. (2009) 'Against localism: does decentralising power to communities fail minorities?', The Political Quarterly, 80(3): 351-360.

Piketty, T. (2014) Capital in the Twenty-First Century, Belknap Press.

Polanyi, K (1944) The Great Transformation: The Political and Economic Origins of Our Time - Beacon Books.

Pugh, M. (2010) Speak for Britain!: A New History of the Labour Party, London: Bodley Head.

Rawls, J. (1971) A Theory of Justice, Cambridge, Massachusetts: Belknap Press of Harvard University Press.

Rawnsley, A (2018) Politicians can't control the digital giants with rules drawn up for the analogue era, Guardian 24th March 2018.

Rousseau, J.J. (1762) The Social Contract or Principles of Political Right, Public Domain Foederis Aequas D.

Ryder, A. (2015) 'Gypsies and Travellers: a big or divided society?', Policy \& Politics, 43(1): 101-117.

Salter, B. (2018). 'When intellectuals fail? Brexit and hegemonic challenge', Competition \& Change, 22(5): 467-487.

Sarup, M. (1991) 'Education and the Ideologies of Racism', Stoke on Trent, Trentham books.

Seikel, D. (2016) A Social and Democratic Europe? Obstacles and Perspectives for Action - Working Paper, Hans Bockler Stiftung.

Seidler, V. (2018) Making sense of Brexit: Democracy, Europe and uncertain futures, Bristol: Policy Press.

Schmitt, C (1976) The Concept of the Political (New Brunswick: Rutgers University Press

Shipman, T. (2016). All Out War: The Full Story of How Brexit Sank Britain's Political Class, London: Harper Collins. 
Sloan, A. and Campbell, I. (2017) 'How did Arron Banks afford Brexit?', Open Democracy [online] 19 October, Available from: https://www. opendemocracy.net/en/dark-money-investigations/how-did-arron-banksafford-brexit/

Solomos, J. and Black, L. (1996) 'Racism and Society', Basingstoke, MacMillan Press

Soros, G (2013) How to save the European Union, The Guardian 9th April 2013. Susen, S (2017) No Exit from Brexit? - Brexit: Sociological Responses, Edited by William Outhwaite. Imprint: Anthem Press.

Stritzel, H. (2007). Towards a Theory of Securitization: Copenhagen and Beyond. European Journal of International Relations, 13(3), 357-383.

UK in a Changing World (2019) Brexit and Public Opinion in 2019.

Young, I. M. (1999) Justice, inclusion, and deliberative democracy, in Macedo, S. (ed.), Deliberative Politics: Essays on Democracy and Disagreement. Oxford University Press.

Wolf, M (2016) Britain's friends are right to fear Brexit - Financial Times $20^{\text {th }}$ April.

Woodward, K. (2002) Identity and difference, London, Sage Publication Ltd. 
